\title{
A!
}

This is an electronic reprint of the original article.

This reprint may differ from the original in pagination and typographic detail.

Muguet, M.C.S.; Ruuttunen, K.; Jääskeläinen, A.S.; Colodette, J.L.; Vuorinen, T.

\section{Thermomechanical pulping of novel Brazilian Eucalyptus hybrids}

Published in:

Holzforschung

DOI:

$10.1515 / \mathrm{hf}-2012-0158$

Published: 01/01/2013

Document Version

Publisher's PDF, also known as Version of record

Please cite the original version:

Muguet, M. C. S., Ruuttunen, K., Jääskeläinen, A. S., Colodette, J. L., \& Vuorinen, T. (2013). Thermomechanical pulping of novel Brazilian Eucalyptus hybrids. Holzforschung, 67(5), 489-495. https://doi.org/10.1515/hf-2012-

0158

This material is protected by copyright and other intellectual property rights, and duplication or sale of all or part of any of the repository collections is not permitted, except that material may be duplicated by you for your research use or educational purposes in electronic or print form. You must obtain permission for any other use. Electronic or print copies may not be offered, whether for sale or otherwise to anyone who is not an authorised user. 


\section{Marcelo Coelho dos Santos Muguet*, Kyösti Ruuttunen, Anna-Stiina Jääskeläinen, Jorge Luiz Colodette and Tapani Vuorinen \\ Thermomechanical pulping of novel Brazilian Eucalyptus hybrids}

\begin{abstract}
The importance of Eucalyptus wood as a sustainable resource is well established. Mechanical pulp production is an energy-intensive process, and methods for decreasing energy demand are needed. In the present article, the structure of Eucalyptus hybrids and the produced pulps from the hybrids were assessed in terms of energy consumption, technical properties, and fiber morphology. The defibration and fiber development were investigated by traditional thermomechanical pulping in laboratory scale. There was no clear difference in the extent of defibration and fibrillation among the hybrids, with the exception of one hybrid (U2xGL1). Guaiacyl lignin contents of more than $7.2 \%$ had a minor influence on energy consumption, and this finding is different from the results of previous studies on chemimechanical pulping processes. However, a low amount of guaiacyl lignin (6.1\% based on wood) decreased the energy demand. This assessment is of major importance concerning the energysaving defibration during thermomechanical pulping production.
\end{abstract}

Keywords: defibration, energy consumption, Eucalyptus, lignin structure, pulp properties, TMP

\footnotetext{
*Corresponding author: Marcelo Coelho dos Santos Muguet, Department of Forest Products Technology, School of Chemical Technology, Aalto University, P.O. Box 16300, Fl-00076 Espoo, Finland, e-mail: marcelo.muguet@aalto.fi, marcelomuguet@gmail.com Kyösti Ruuttunen and Tapani Vuorinen: Department of Forest Products Technology, School of Chemical Technology, Aalto University, P.O. Box 16300, Fl-00076 Espoo, Finland Anna-Stiina Jääskeläinen: VTT Technical Research Centre of Finland, Tietotie 2, Fl-02044, Espoo, Finland

Jorge Luiz Colodette: Laboratório de Celulose e Papel, Universidade Federal de Viçosa, Campus UFV, Viçosa, Minas Gerais 36570-000, Brazil
}

\section{Introduction}

Eucalyptus wood has become one of the most important fiber sources for the forest industries all over the world due to its fast growth in certain regions and its fairly good wood quality for a variety of applications. Eucalyptus has especially good properties for the production of chemical pulps (Magaton et al. 2009). Moreover, Eucalyptus fibers have a high potential as a reinforcement in biocomposites (Tonoli et al. 2009, 2010a). For example, Eucalyptus fibers produced by the mechanical processes, which have high lignin content, improve the long-term performance of the fiber-cement composites (Tonoli et al. 2010b; Muguet et al. 2012). The refining of thermomechanical pulping (TMP) can be thought to involve two main phases: (1) defibration or fiber separation, where the wood matrix is softened, and the separation of fiber bunches and single fibers begins, and (2) fiber development, where the wood fibers start to be disintegrated with the main effects, such as delamination and internal fibrillation (Fernando and Daniel 2008; Fernando et al. 2011, 2012).

There are several data available concerning Eucalyptus mechanical pulp production (Cort and Bohn 1991; Area et al. 1995, 1998, 2007; Xu et al. 1996; Ognar and Xu 1998; Xu and Sabourin 1999; Jones and Richardson 2000, 2001; Browne et al. 2001; Xu 2002; Area and Kruzolek 2008; Muguet et al. 2012). However, the high amount of energy demand during mechanical pulping is a key limiting factor for the process feasibility (Browne et al. 2001). Therefore, understanding the defibration as well as the factors affecting it is necessary. Chips' chemical pretreatment and the application of enzymes have been shown already to decrease energy consumption during refining (Cort and Bohn 1991; Area et al. 1995; Xu et al. 1996; Xu and Sabourin 1999; Xu 2002; Hart et al. 2009a,b; Masarin et al. 2009; Lecourt et al. 2010; Li et al. 2011). In addition, energy demand can be decreased by reducing raw materials variability (Dundar et al. 2009) or by changing the spout angle of wood chipper (Hellström et al. 2011). In TMP production, however, other factors have been shown to decrease the energy demand, such as decreasing discharge consistency from the primary refiner, on a double-stage refiner (Alami et al. 1997), increasing refining temperature/pressure (Muhíc et al. 2010), and compressing chips before refining (Gorski et al. 2010). Earlywood and latewood fractions of wood also have been 
shown to affect TMP process energy demand (Lanouette et al. 2010).

The studies regarding the understanding of the main variables affecting the refining energy demand, such as the chemical and morphologic structure of wood, are scarce. Such studies may have important implications because the results may open new possibilities for hardwood TMP production.

Lignins in hardwoods consist mainly of guaiacyl units (i.e., G units, with one methoxy group in the aromatic ring) and syringyl units (i.e., $\mathrm{S}$ units, with two methoxy groups) (Sarkanen and Ludwig 1971; Boerjan et al. 2003). In our previous studies (Muguet et al. 2012), high $\mathrm{G}$ unit contents of Eucalyptus hybrids increased the specific energy consumption (SEC) during alkaline peroxide mechanical pulping (APMP). However, it would be also important to understand the behavior of Eucalyptus wood in nonchemical systems. TMP has been shown to be feasible in industrial scale for softwoods and in case of some hardwoods, such as aspen wood. A deeper understanding of the factors of SEC of hardwoods might contribute to more production of TMP from hardwoods. New results may also serve as guidelines for the traditional and genetic breeding of trees, which could lead to hybrids with less energy demand during TMP production.

In this work, mainly traditional TMP processes were in focus. The objective was the evaluation of the behavior of a new generation of Eucalyptus hybrids during the process. Relations are sought for between the structural components of wood, focusing mainly on lignin, and the SEC development of fibers and their properties during TMP production.

\section{Material and methods}

Four different hybrids of Brazilian-grown Eucalyptus trees were in focus, which are from the Brazilian Network of Eucalyptus Genome Research - Genolyptus (a nationwide network of laboratories and forestry companies devoted to an integrated molecular breeding approach) (Grattapaglia 2004). The wood samples are coded based on the crossings: E. urophylla $\times E$. globulus (U2xGL1), $[E$. dunnii $\times E$. grandis $] \times E$. globulus $(\mathrm{DGxGL2}), E$. grandis $\times[E$. urophylla $\times E$. globulus] $(\mathrm{G} 1 \mathrm{xUGL})$, and $[E$. dunnii $\times E$. grandis $] \times E$. urophylla (DGxU2). These hybrids were chosen from 18 other hybrids of the same Genolyptus project due to their similarities in chemical and physical characteristics. Such properties ensure that differences in total carbohydrate and total lignin content, density, and some morphologic features (e.g., cell wall thickness) would have a minimum impact on the SEC variations. However, the guaiacyl lignin (G lignin) content differed notably (in the range of $6.1-8.3 \%$ based on wood; Table 1) among the hybrids. The
Table 1 Chemical and physical characterization of the Eucalyptus hybrids investigated.

\begin{tabular}{lrrrr}
\hline $\begin{array}{l}\text { Composition, } \\
\text { properties }\end{array}$ & \multicolumn{3}{c}{ Eucalyptus hybrids } \\
\cline { 2 - 5 } & U2xGL1 & DGxGL2 & G1xUGL & DGxU2 \\
\hline Carbohydrates (\%) & & & & \\
$\quad$ Glucans & 46.8 & 46.8 & 46.2 & 46.6 \\
$\quad$ Xylans & 13.7 & 13.2 & 13.6 & 12.9 \\
$\quad$ Others & 2.3 & 1.4 & 2.1 & 2.2 \\
Lignin (\%) & & & & \\
$\quad$ Klason & 24.3 & 24.4 & 25.4 & 26.2 \\
Acid soluble & 5.8 & 4.5 & 5.0 & 4.5 \\
$\quad$ Total & 30.1 & 28.9 & 30.4 & 30.7 \\
S/G ratios & 4.0 & 3.0 & 3.1 & 2.7 \\
Guaiacyl units (\%) & 6.1 & 7.2 & 7.4 & 8.3 \\
Acetyl groups (\%) & 2.7 & 2.6 & 2.9 & 2.6 \\
Uronic acids (\%) & 4.1 & 3.9 & 4.0 & 4.1 \\
Density (kg m-3) & 506 & 489 & 500 & 496 \\
\hline
\end{tabular}

All percentages are based on wood. For the explanation of the abbreviations, see Materials and methods.

syringyl-to-guaiacyl (S/G) ratio was determined by the nitrobenzene oxidation method (Lin and Dence 1992) and the G lignin content was calculated taking into account the $S / G$ values and the total lignin content from the wood samples.

Wood density was evaluated according to the TAPPI standard T258 om-06. The carbohydrate composition was analyzed by highperformance anion exchange chromatography with pulsed amperometric detection after acid hydrolysis following the procedure described by Wallis et al. (1996). Klason lignin and acid soluble lignin were measured according to Gomide and Demuner (1986) and Goldschmid (1971), respectively. Lignin content was defined as the sum of Klason and acid soluble lignin as described by Dence (1992). S/G ratio was evaluated according to Lin and Dence (1992). Total uronic acids and acetyl groups were evaluated according to Scott (1979) and Solar et al. (1987), respectively.

The TMP process was carried out in two steps: (1) The wood chips were impregnated with deionized water in a rotating digester. To ensure complete saturation of the chips, 10 bar of pure oxygen was inserted in the digester, for $5 \mathrm{~h}$, at $4 \mathrm{l} \mathrm{kg}^{-1}$ liquid-to-wood ratio and $25^{\circ} \mathrm{C}$. Then, the chips were removed from the digester and rested for at least $48 \mathrm{~h}$ at room temperature and atmospheric pressure in sealed containers. (2) The mechanical defibration was carried out on $100 \mathrm{~g}$ o.d. chips samples in a wing defibrator consisting of four static blades; the refining gap between blades and inner refiner wall was $1.0 \mathrm{~mm}$. Other parameters are as follows: approximately $750 \mathrm{rpm}$; at approximately $37 \%$ consistency; $130^{\circ} \mathrm{C}$; and refining times of 5 , 10 , and $15 \mathrm{~min}$. Before the refining experiments, the chips were preheated inside the refiner for $5 \mathrm{~min}$, and the condensate was released before the refining process started. Pulps were screened with a slot screener of $0.17 \mathrm{~mm}$ and tested for Canadian Standard Freeness (ISO 5267-2:2001). Handsheets were prepared (ISO 5269:1:2005) and tested for grammage (ISO 536:1995), density (ISO 534:1988), tear strength (ISO 1974:1990, Elmendorf method), tensile index (SCAN-P38), and opacity and brightness (ISO 2470:1999). Fiber morphologic analyses were carried out with FiberLab analyzer (Metso Automation, Vantaa, Finland). 


\section{Results and discussion}

\section{TMP refinings}

Because the wood composition is similar among the samples (Table 1), the refining behavior of almost all hybrids is also similar; an exception is the U2xGL1 hybrid (Figure 1a).

It is worth noting that the refiner used in this study, based on blades, consumes more energy than pilot-scale or industrial disc refiners (Xu and Sabourin 1999; Jones and Richardson 2000, 2001). It was assumed that, at least as an approximation, the total applied energy with different refining systems will be proportional to the energy that manifests itself as changes to the fibers (Muguet et al. 2012). Table 2 shows the summary of the refining results. The content of rejects after $0.17 \mathrm{~mm}$ screening is in line
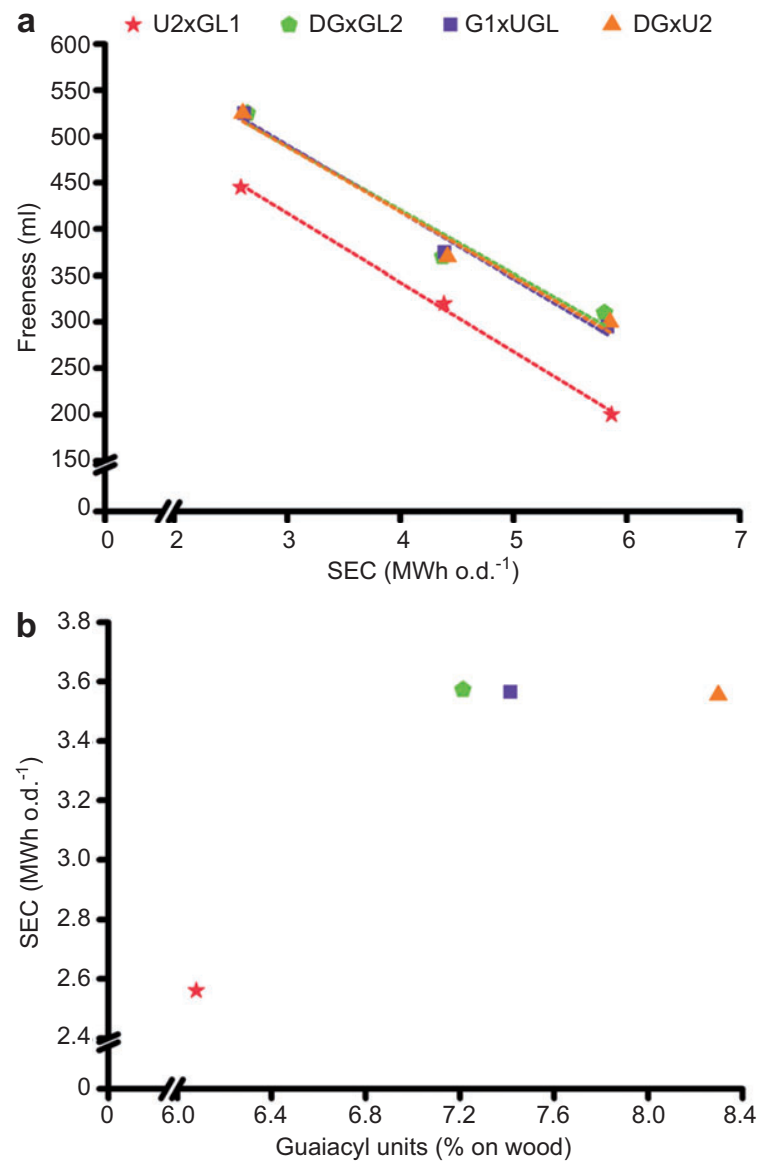

Figure 1 Relation of the SEC to (a) freeness (Canadian Standard Freeness) and (b) guaiacyl units at the freeness level of $450 \mathrm{ml}$ in Eucalyptus hybrids.

For the explanation of the abbreviations, see Materials and methods.
Table 2 Summary of the results of TMP refining experiments of Eucalyptus hybrids.

\begin{tabular}{lrrrrr}
\hline $\begin{array}{l}\text { Eucalyptus } \\
\text { hybrids }\end{array}$ & $\begin{array}{r}\text { Refining } \\
\text { time (min) }\end{array}$ & $\begin{array}{r}\text { SEC (MWh } \\
\left.\text { odt }^{-1}\right)\end{array}$ & $\begin{array}{r}\text { Freeness, } \\
\text { CSF (ml) }\end{array}$ & $\begin{array}{r}\text { Rejects } \\
\text { (\%) }\end{array}$ & $\begin{array}{r}\text { Fines } \\
\text { (\%) }\end{array}$ \\
\hline U2xGL1 & 5 & 2.59 & 445 & 3.4 & 21.8 \\
& 10 & 4.39 & 320 & 2.5 & 22.2 \\
& 15 & 5.87 & 200 & 2.5 & 22.0 \\
DGxGL2 & 5 & 2.65 & 525 & 4.8 & 19.9 \\
& 10 & 4.37 & 370 & 3.6 & 15.3 \\
& 15 & 5.80 & 310 & 3.4 & 15.3 \\
G1xUGL & 5 & 2.62 & 525 & 2.2 & 14.0 \\
& 10 & 4.39 & 375 & 2.2 & 14.6 \\
& 15 & 5.83 & 295 & 1.2 & 12.5 \\
DGxU2 & 5 & 2.62 & 525 & 3.4 & 22.1 \\
& 10 & 4.42 & 370 & 3.3 & 20.9 \\
& 15 & 5.85 & 300 & 2.8 & 20.6 \\
\hline
\end{tabular}

For the explanation of the abbreviations, see Materials and methods. CSF, Canadian Standard Freeness.

with TMP production data from other wood types (Lönnberg 2009). Obviously, the amount of fines approximately follows the trend of rejects content.

The lignin glass transition temperature has a direct influence on the defibration. At temperatures below the lignin glass transition temperature, the cell wall can be considered as consisting of largely tangentially oriented lamellae of two zones, each of which has both hard and soft components. This means that the microfibrils consist of crystalline cellulose (stiff and "hard" segments) and the paracrystalline cellulose (as "soft" segments), which is surrounded by a matrix, and also consist of the soft and hard components, namely from the "soft" hemicelluloses and the "hard" lignin. Each zone is incompletely softened, and the overall fracture modulus of the wood remains high (Irvine 1985). That is the case of the TMP process, where the lignin as the main component of the compound middle lamella (CML) remains hard, whereas the rest of the cell wall is more softened. In this case, the defibration takes place mostly in the segment between the primary wall and the S1 layer of the secondary fiber wall. However, in a chemimechanical process, such as chemithermomechanical pulp and APMP processes, where wood is treated with chemicals before defibration, the lignin properties are altered in such a way that the softening temperature is lowered. This leads to improved defibration, which takes place mostly on the middle lamella or CML (Franzén 1986). Our previous studies (Muguet et al. 2012) showed a high positive correlation between the $G$ lignin content and the SEC to reach a given freeness level. This observation was interpreted as that the G lignins of 
Table 3 Summary of physical, mechanical, and optical properties of pulp samples derived from Eucalyptus hybrids.

\begin{tabular}{|c|c|c|c|c|c|c|c|c|c|c|c|c|}
\hline \multirow{2}{*}{$\begin{array}{l}\text { Properties } \\
\text { Refining time (min) }\end{array}$} & \multicolumn{3}{|c|}{ U2xGL1 } & \multicolumn{3}{|c|}{ DGxGL2 } & \multicolumn{3}{|c|}{ G1xUGL } & \multicolumn{3}{|r|}{ DGxU2 } \\
\hline & 5 & 10 & 15 & 5 & 10 & 15 & 5 & 10 & 15 & 5 & 10 & 15 \\
\hline Freeness, CSF (ml) & 445 & 320 & 200 & 525 & 370 & 310 & 525 & 375 & 295 & 525 & 370 & 300 \\
\hline Sheet density $\left(\mathrm{kg} \mathrm{m}^{-3}\right)$ & 290.0 & 311.2 & 335.7 & 271.4 & 300.0 & 304.5 & 284.6 & 317.5 & 319.0 & 261.0 & 290.0 & 306.7 \\
\hline Tear index $\left(\mathrm{mN} \mathrm{m}^{2} \mathrm{~g}^{-1}\right)$ & 1.18 & 1.51 & 1.75 & 1.00 & 1.41 & 1.45 & 1.07 & 1.36 & 1.45 & 0.87 & 1.10 & 1.25 \\
\hline Tensile index $\left(\mathrm{kN} \mathrm{m} \mathrm{kg}^{-1}\right)$ & 7.8 & 11.7 & 14.8 & 5.8 & 11.5 & 12.8 & 6.2 & 11.1 & 12.8 & 4.5 & 7.5 & 9.7 \\
\hline Opacity (\%) & 99.0 & 99.2 & 99.5 & 99.2 & 99.5 & 99.6 & 98.7 & 99.1 & 99.4 & 99.6 & 99.8 & 99.8 \\
\hline Brightness (\% ISO) & 49.7 & 49.9 & 50.0 & 44.8 & 45.5 & 44.9 & 46.0 & 46.8 & 46.9 & 37.6 & 38.7 & 38.1 \\
\hline
\end{tabular}

For the explanation of the abbreviations, see Materials and methods. CSF, Canadian Standard Freeness.

hardwoods are mainly located in the CML of fibers and in the wall of vessels (Musha and Goring 1975). The validity of this was also shown for Eucalyptus wood (Watanabe et al. 2004). The content of $G$ lignin varies notably among the Eucalyptus wood hybrids listed in Table 1. Figure $1 \mathrm{~b}$ shows the relationship between $\mathrm{G}$ unit content and SEC to reach a $450 \mathrm{ml}$ freeness. In the case of the U2xGL1 hybrid, the value was obtained by extrapolation (Figure 1a). The energy demand in three cases of the four is very similar probably because of the low amount of $G$ units in the fibers' secondary wall of hardwoods (Musha and Goring 1975; Watanabe et al. 2004).

However, the SEC for the U2xGL1 hybrid was substantially lower compared with the other samples to reach a given freeness ( $450 \mathrm{ml})$. This can be explained by the low $\mathrm{G}$ content in the wood of this hybrid. G lignin moieties are known to increase the glass transition temperature of lignins probably because they increase the cross-linking density of lignins (Olsson and Sálmen 1997).

\section{Pulp physical, mechanical, and optical properties}

Ideally, paper sheets from TMP should have high opacity, brightness, bulk, smoothness, as well as suitable pore structure at low grammage, without the need of excessive reinforcement (Lönnberg 2009). Table 3 shows the summary of the handsheets properties. The differences in the brightness values among the hybrids reflect the natural differences in the color of the wood material. Expectedly, sheet density tends to increase with longer refining times as the more flexible fibers increase the relative bonding area. External fibrillation also induces sheet density increment by intensifying interfiber bonding.

Tensile index gives indications of how paper web will behave on the manufacturing process and can be highly affected by bonding strength between fibers, stiffness, and fiber length. In general, the tensile index values were low for all four hybrids, but are in line with previous results, at the same density level (Xu and Sabourin 1999; Muguet et al. 2012). Particularly, DGxGL2 and DGxU2 had similar fiber length, fiber width, and fibrillation index (Table 4). However, the fines content of DGxGL2 is slightly lower than of DGxU2, which could indicate that the fines are acting like spacers, reducing bonding ability and thus lowering both tensile and tear index values.

Tear index is mainly influenced by fiber strength and fiber length (Kärenlampi 1996). Differences can be seen for tear index, being greater for U2xGL1 hybrid. Some of the fiber morphologic characteristics, such as fibrillation index, have a great influence on tear index, which will be discussed on the next section. In addition, tear index is better interpretable when correlated with tensile index, because the former is related to intrinsic fiber strength and the latter is more connected to fiber bonding strength (Figure 2a). The great correlation demonstrates that woods with less favorable properties could be improved by more intense refining.

Table 4 Summary of morphologic properties of pulp fibers derived from all four Eucalyptus hybrids.

\begin{tabular}{lrrrrr}
\hline Hybrids & $\begin{array}{r}\text { Refining } \\
\text { time min }\end{array}$ & $\begin{array}{r}\text { Curl } \\
(\%)\end{array}$ & $\begin{array}{r}\text { Fibrillation } \\
(\%)\end{array}$ & $\begin{array}{r}\text { Length } \\
(\mathbf{m m})\end{array}$ & $\begin{array}{r}\text { Width } \\
(\mu \mathrm{m})\end{array}$ \\
\hline U2xGL1 & 5 & 6.7 & 2.60 & 0.47 & 15.86 \\
& 10 & 6.6 & 3.26 & 0.46 & 15.42 \\
& 15 & 6.5 & 3.52 & 0.46 & 15.42 \\
DGxGL2 & 5 & 6.0 & 2.11 & 0.48 & 17.37 \\
& 10 & 6.5 & 2.60 & 0.50 & 17.20 \\
& 15 & 5.6 & 2.90 & 0.51 & 16.45 \\
G1xUGL & 5 & 7.4 & 2.06 & 0.57 & 16.83 \\
& 10 & 6.7 & 2.61 & 0.60 & 16.70 \\
& 15 & 7.1 & 2.72 & 0.58 & 16.25 \\
DGxU2 & 5 & 5.2 & 1.80 & 0.47 & 17.00 \\
& 10 & 5.7 & 2.31 & 0.46 & 16.52 \\
& 15 & 5.0 & 2.39 & 0.47 & 16.37 \\
\hline
\end{tabular}



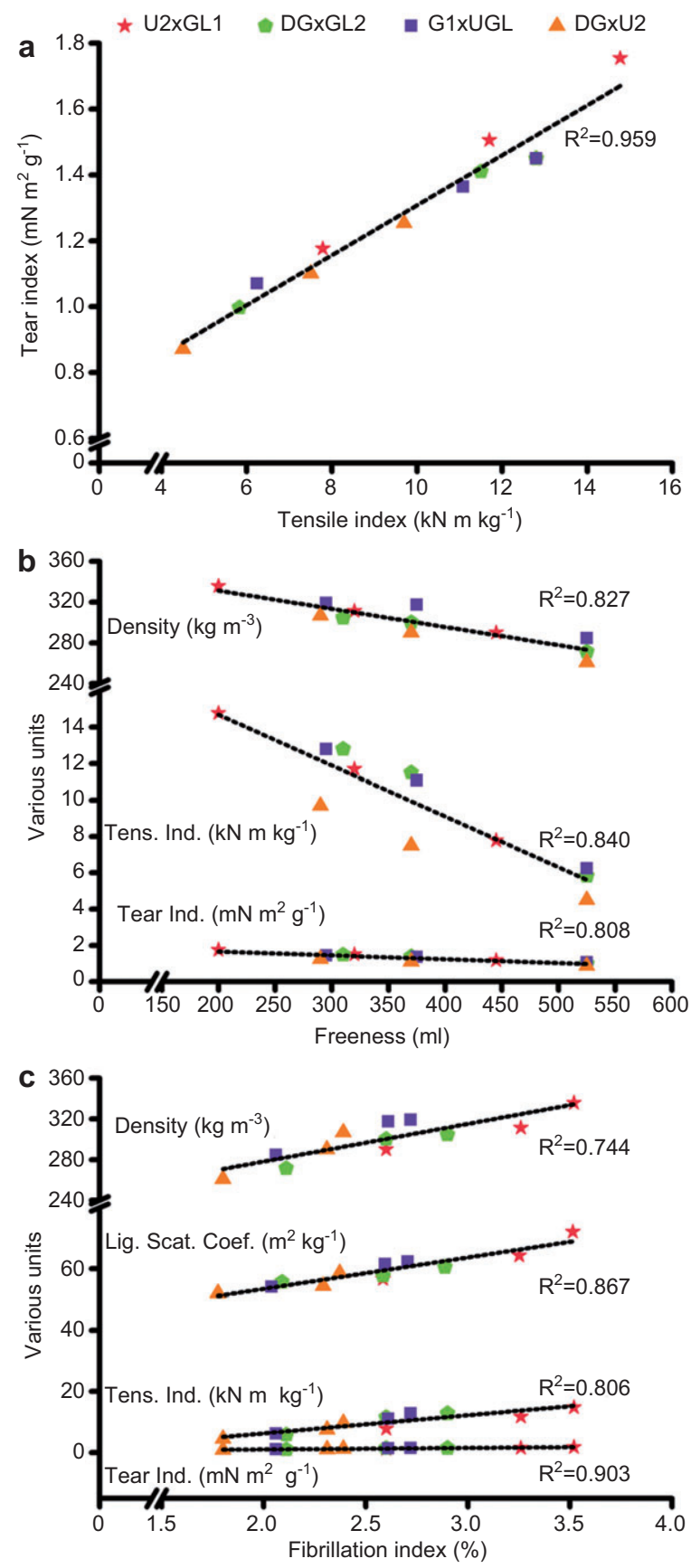

Figure 2 Summary of physical, mechanical, optical, and morphologic properties for all three refining levels from the four Eucalyptus hybrid pulp samples investigated.

Tens. Ind., Tensile index; Tear ind., tear index; Lig. Scat. Coef., light scattering coefficient.

This correlation also indicates differences in refinability, especially between U2xGL1 and its counterparts (Figure 2a), which can be also shown when plotting all results together (Figure 2b). High correlation indices for sheet density, tensile, and tear strength can be found. As aforementioned, counterparts with low refinability could match their counterparts on more intense refining. An interesting feature is that the hybrid DGxU2 was the one with lowest values in all technical properties assessed, which could also be seen for APMP processes (Muguet et al. 2012).

As discussed previously, the $\mathrm{G}$ units did not have great influence on the defibration, with the exception of the U2xGL1 hybrid, which showed better technical properties in comparison with the other hybrids. However, the fiber development across the refining seems to have also an effect. This is a hint to the important role of morphologic properties in terms of the fiber development and the resulting papermaking properties.

\section{Fiber morphology}

Fiber morphologic characteristics, such as microfibril angle (Page et al. 1977; Salmén and De Ruvo 1985), coarseness, fiber length (El-Hosseiny and Anderson 1999), curl index (Mohlin and Alfredsson 1990; Fellers et al. 2001), have been shown to be of extreme importance for pulp and paper properties. Table 4 shows the summary of these morphologic features. Prinsen et al. (2012) evaluated wood fibers' properties from both G1xUGL and DGxU2 hybrids. Fiber width results are in line with the morphologic characteristics from the wood fibers (higher fraction of $12-23 \mu \mathrm{m}$ ), which is an indication that the presence of fiber bundles on the final pulp is minimal. Because wood density values of all hybrids are similar, the conclusions regarding fiber width are also valid for the U2xGL1 and DGxGL2 hybrids.

There is no strong correlation between the morphologic properties on the one hand and the physical and mechanical properties on the other, with the exception of the fibrillation index. External fibrillation has been already shown to have an effect on tensile strength (Kang and Paulapuro 2006); however, in other studies (Hartman 1984; Kang et al. 2006), such trend was not clear. In this study, fibrillation index has a strong effect on the physical, mechanical, and optical properties of the handsheets prepared from the TMP pulps (Figure 2c).

External fibrillation enhances interfiber bonding, enhancing the compatibility of the fiber network (density), which reflects directly on mechanical properties (e.g., tensile and tear indices). The intensity of fibrillation induces the formation of different types of fines, which affects directly the light scattering coefficient. In addition, opacity has an inverse correlation with curl index $\left(R^{2}=0.623\right)$. Mohlin and Alfredsson (1990) showed that the fibrillation index has an effect on light scattering. 
Seemingly, curled fibers of the handsheets tend to increase light absorption across the sheet Z-profile, decreasing the light transmission.

\section{Conclusions}

TMP of Eucalyptus is challenging, especially regarding the high energy demand of the process. G lignin contents of more than $7.2 \%$ (based on wood) had a minor influence on energy consumption, but the SEC was lower beginning with $\mathrm{G}$ lignin content of approximately $6.1 \%$ (based on wood), which was the case in the hybrid U2xGL1. However, it is not possible to give an exact threshold value, which is relevant for SEC lowering. The macrocharacteristics of the investigated Eucalyptus hybrid samples, such as density and total carbohydrate contents, and their influence on the SEC is complex.
Moreover, no experiments could be carried out with Eucalyptus samples with G lignin content between 6.1\% and $7.2 \%$. Therefore, the results must be interpreted with care. More in-depth studies are needed to understand the complexity of influence of glass transition temperature of lignins and the hemicelluloses on the defibration mechanism and the SEC of TMP.

Acknowledgments: The authors would like to acknowledge the financial support from the Academy of Finland (Effect of fibre wall chemistry on energy demand in wood defibration, DEFIBRE) and the Conselho Nacional de Desenvolvimento Científico e Tecnológico (Brazil). The authors would also like to acknowledge José Maurício Lino for the wood chemical characterization and Heikki Tulokas for the help during refining experiments.

Received September 24, 2012; accepted December 5, 2012; previously published online January 14, 2013

\section{References}

Alami, R., Boileau, I., Harris, G., Lachaume, J., Karnis, A., Miles, K.B., Roche, A. (1997) Impact of refining intensity on energy reduction in commercial refiners: effect of primary-stage consistency. Tappi J. 80:185-193.

Area, M.C., Kruzolek, C. (2008) Alternatives to alkaline peroxide mechanical pulping of Eucalyptus grandis wood. Rev. Cienc. Technol. 10b:3-9.

Area, M.C., Gavazzo, G.B., Felissia, F.E., Valade, J.L. (1995) Chemimechanical pulping of Eucalyptus grandis. Wood Fiber Sci. 27:368-378.

Area, M.C., Felissia, F.E., Barboza, O.M. (1998) Optimization of one-stage bleaching of industrial chemical mechanical pulps. Invest. Tec. Pap. 35:635-651.

Area, M.C., Felissia, F.E., Clermont, J.E., Nunez, C.E., Venica, A.D. (2007) Bleached NSSC pulps from Eucalyptus species. Cell. Chem. Technol. 41:193-200.

Boerjan, W., Ralph, J., Baucher, M. (2003) Lignin biosynthesis. Annu. Rev. Plant Biol. 54:519-546.

Browne, T.C., Francis, D.W., Towers, M.T. (2001) Energy cost reduction in the pulp and paper industry: an overview. Pulp Pap. Can. 102:26-30.

Cort, C.J., Bohn, W.L. (1991) Alkaline peroxide mechanical pulping of hardwoods. Tappi J. 74:79-84.

Dence, C.W. (1992) The determination of lignin. Methods Lignin Chem. 33-61.

Dundar, E., Laperrière, L., Ding, F. (2009) Decreasing specific energy of thermomechanical pulps from reduction of raw materials variability. Tappi J. 8:23-29.

El-Hosseiny, F., Anderson, D. (1999) Effect of fiber length and coarseness on the burst strength of paper. Tappi J. 82:202203.

Fellers, C., Melander, J., Mohlin, U. (2001) Predicting the effect of reinforcement pulp characteristics in TMP papers for web breaks using fracture mechanics. Nord. Pulp Pap. Res. J. 16:257-260.

Fernando, D., Daniel, G. (2008) Exploring Scots pine fibre development mechanisms during TMP processing: impact of cell wall ultrastructure (morphological and topochemical) on negative behaviour. Holzforschung 62:597-607.

Fernando, D., Muhíc, D., Engstrand, P., Daniel, G. (2011) Fundamental understanding of pulp property development under different thermomechanical pulp refining conditions as observed by a new Simons' staining method and SEM observation of the ultrastructure of fibre surfaces. Holzforschung 65:777-786.

Fernando, D., Muhíc, D., Engstrand, P., Daniel, G. (2012) Surface and internal micro/ultrastructure of TMP fibres produced during high-intensity refining elucidate the development of pulp and paper properties. Holzforschung 66:467-475.

Franzén, R. (1986) General and selective upgrading of mechanical pulps. Nord. Pulp Pap. Res. J. 1:4-13.

Goldschmid, O. (1971) Ultraviolet spectra. In: Lignins: Occurrence, Formation, Structure and Reactions. Eds. Sarkanen, K.V., Ludwig, C.H. John Wiley and Sons, New York. pp. 241-266.

Gomide, J.L., Demuner, B.J. (1986) Determinação do teor de lignina em material lenhoso: método klason modificado. Papel 47:36-38.

Gorski, D., Hill, J., Engstrand, P., Johansson, L. (2010) Review: reduction of energy consumption in TMP refining through mechanical pretreatment of wood chips. Nord. Pulp Pap. Res. J. 25:156-161.

Grattapaglia, D. (2004) Integrating genomics into Eucalyptus breeding. GMR Genet. Mol. Res. 3:369-379.

Hart, P.W., Waite, D.M., Thibault, L., Tomashek, J., Rousseau, M., Hill, C., Sabourin, M.J. (2009a) Refining energy reduction and pulp characteristic modification of alkaline peroxide 
mechanical pulp (APMP) through enzyme application. Tappi J. 8:19-25.

Hart, P.W., Waite, D.M., Thibault, L., Tomashek, J., Rousseau, M., Hill, C., Sabourin, M.J. (2009b) Selective enzyme impregnation of chips to reduce specific refining energy in alkaline peroxide mechanical pulping. Holzforschung 63:418-423.

Hartman, R.R. (1984) Mechanical treatment of pulp fibers for property development. Doctoral dissertation, Georgia Institute of Technology, Atlanta, GA.

Hellström, L.M., Gradin, P.A., Engstrand, P., Gregersen, Ø. (2011) Properties of wood chips for thermomechanical pulp (TMP) production as a function of spout angle. Holzforschung 65:805-809.

Irvine, G.M. (1985) The significance of the glass transition of lignin in thermomechanical pulping. Wood Sci. Technol. 19: 139-149.

Jones, T.G., Richardson, J.D. (2000) Chemimechanical pulping of New Zealand grown Eucalyptus fastigata. Appita J. 53:398-403. Jones, T.G., Richardson, J.D. (2001) Chemimechanical pulping of New Zealand-grown Eucalyptus regnans. Appita J. 54:265-271.

Kang, T., Paulapuro, H. (2006) Effect of external fibrillation on paper strength. Pulp Pap. Can. 107:51-54.

Kang, T., Somboon, P., Paulapuro, H. (2006) Fibrillation of mechanical pulp fibers. Pap. Puu 88:409-411.

Kärenlampi, P.P. (1996) The effect of pulp fiber properties on the tearing work of paper. Tappi J. 79:211-216.

Lanouette, R., Law, K., Huang, F. (2010) Impact of early- and latewood on thermomechanical pulping. Appita J. 63: 120-125.

Lecourt, M., Meyer, V., Sigoillot, J.-C., Petit-Conil, M. (2010) Energy reduction of refining by cellulases. Holzforschung 64:441-446.

Li, X., Cai, Z., Horn, E., Winandy, J.E. (2011) Effect of oxalic acid pretreatment of wood chips on manufacturing medium-density fiberboard. Holzforschung 65:737-741.

Lin, S.Y., Dence, C.W. Methods in Lignin Chemistry. Springer-Verlag, New York, 1992.

Lönnberg, B. (2009) Idea of mechanical pulping. In: Mechanical Pulping. Ed. Lönnberg, B. Paper Engineers' Association, Helsinki, Finland. pp. 18-22.

Magaton, A.d.S., Colodette, J.L., Gouvêa, A.d.F.G., Gomide, J.L., Muguet, M.C.S., Pedrazzi, C. (2009) Eucalyptus wood quality and its impact on kraft pulp production and use. Tappi J. 8:32-39.

Masarin, F., Pavan, P.C., Vicentim, M.P., Souza-Cruz, P.B., LoguercioLeite, C., Ferraz, A. (2009) Laboratory and mill scale evaluation of biopulping of Eucalyptus grandis Hill ex Maiden with Phanerochaete chrysosporium RP-78 under non-aseptic conditions. Holzforschung 63:259-263.

Mohlin, U.B., Alfredsson, C. (1990) Fiber deformation and its implications in pulp characterization. Nord. Pulp Pap. Res. J. 5:172-179.

Muguet, M.C.S., Colodette, J.L., Jääskeläinen, A.-S. (2012) Alkaline peroxide mechanical pulping of novel Brazilian Eucalyptus hybrids. BioResources 7:3823-3836.

Muhíc, D., Sundström, L., Sandberg, C., Ullmar, M., Engstrand, P. (2010) Influence of temperature on energy efficiency in double disc chip refining. Nord. Pulp Pap. Res. J. 25:420-427.
Musha, Y., Goring, D.A.I. (1975) Distribution of syringyl and guaiacyl moieties in hardwoods as indicated by ultraviolet microscopy. Wood Sci. Technol. 9:45-58.

Ognar, G., Xu, E.C. (1998) Mechanical pulping of hardwood and its applications. Proceedings of the International Symposium on Energizing Technologies of Pulping and Papermaking of Fast-Growing Wood. pp. 225-234.

Olsson, A., Sálmen, L. (1997) The effect of lignin composition on the viscoelastic properties of wood. Nord. Pulp Pap. Res. J. 12:140-144.

Page, D.H., El-Hosseiny, F., Winkler, K., Lancaster, A.P.S. (1977) Elastic modulus of single pulp fibers. Tappi J. 60:114-117.

Prinsen, P., Gutiérrez, A., Rencoret, J., Nieto, L., Jiménez-Barbero, J., Burnet, A., Petit-Conil, M., Colodette, J.L., Martínez, A.T., del Río, J.C. (2012) Morphological characteristics and composition of lipophilic extractives and lignin in Brazilian woods from different eucalypt hybrids. Ind. Crops Prod. 36:572-583.

Salmén, L., De Ruvo, A. (1985) A model for the prediction of fiber elasticity. Wood Fiber Sci. 17:336-350.

Sarkanen, K.V., Ludwig, C.H. Lignins-Occurrence, Formation, Structure and Reactions. Wiley-Interscience, New York, 1971.

Scott, R.W. (1979) Colorimetric determination of hexuronic acids in plant materials. Anal. Chem. 51:936-941.

Solar, R., Kacik, F., Melcer, I. (1987) Simple semimicro method for the determination of 0 -acetyl groups in wood and related materials. Nord. Pulp Pap. Res. J. 2:139-141.

Tonoli, G.H.D., Fuente, E., Monte, C., Savastano Jr., H., Lahr, F.A.R., Blanco, A. (2009) Effect of fibre morphology on flocculation of fibre-cement suspensions. Cem. Concr. Res. 39:1017-1022.

Tonoli, G.H.D., Savastano, H., Fuente, E., Negro, C., Blanco, A., Rocco Lahr, F.A. (2010a) Eucalyptus pulp fibres as alternative reinforcement to engineered cement-based composites. Ind. Crops Prod. 31:225-232.

Tonoli, G.H.D., Almeida, A.E.F.S., Pereira-da-Silva, M.A., Bassa, A., Oyakawa, D., Savastano Jr., H. (2010b) Surface properties of Eucalyptus pulp fibres as reinforcement of cement-based composites. Holzforschung 64:595-601.

Wallis, A.F.A., Wearne, R.H., Wright, P.J. (1996) Chemical analysis of polysaccharides in plantation eucalypt woods and pulps. Appita J. 49:258-262.

Watanabe, Y., Kojima, Y., Ona, T., Asada, T., Sano, Y., Fukazawa, K., Funada, R. (2004) Histochemical study on heterogeneity of lignin in Eucalyptus species II. The distribution of lignins and polyphenols in the walls of various cell types. Int. Assoc. Wood Anat. J. 25:283-295.

Xu, E.C. (2002) P-RC alkaline peroxide mechanical pulping of hardwoods. Part 3. South American eucalypts. Appita J. 55:130-134.

Xu, E.C., Sabourin, M.J. (1999) Evaluation of APMP and CTMP for market pulps from South American Eucalyptus. Tappi J. 82:75-82.

Xu, E.C., Sabourin, M.J., Cort, J.B. (1996) Evaluation of APMP and BCTMP processes for market pulp properties from South American Eucalyptus species. Pulp. Conf. 2:705-717. 